\title{
Preparation and use of a glyceryl triether as an indicator of fat absorption
}

\author{
BY W. E. CARLSON* AND H. S. BAYLEY \\ Department of Nutrition, University of Guelph, Guelph, Ontario, Canada
}

(Received 31 August 197I - Accepted 21 February 1972)

\begin{abstract}
I. Tridodecyl glyceryl ether (1,2,3-tridodecoxypropane) was prepared and purified for use as a lipid-soluble indicator of fat absorption. It was separated from other lipids present in samples of diet, digesta and faeces by thin-layer chromatography and determined by gasliquid chromatography.

2. In balance studies using rats which received a semi-purified diet containing beef tallow, $97^{-98} \%$ of both the dietary tridodecyl glyceryl ether and of the chromic oxide $\left(\mathrm{Cr}_{2} \mathrm{O}_{3}\right)$ from the diet were recovercd unaltered from the faeces. This suggests that both compounds are equally good as digestibility indicators.

3. When the rats were killed, analyses of digesta taken from different regions of the gastrointestinal tract showed that, although the $\mathrm{Cr}_{2} \mathrm{O}_{3}$ passed from the stomach faster than did the fat, the triether and fat left the stomach together. This suggested that the triether was more suitable as an indicator of fat absorption in the digestive tract than is $\mathrm{Cr}_{2} \mathrm{O}_{3}$.

4. Comparisons of the digesta removed from the stomach, jejunum, and ileum of piglets receiving a semi-purified diet containing beef tallow, tridodecyl glyceryl ether, $\mathrm{Cr}_{2} \mathrm{O}_{3}$ and ${ }^{14} \mathrm{C}$-labelled oleic acid also supported the conclusion that the triether was a suitable indicator of fat absorption from diffcrent regions of the digestive tract.
\end{abstract}

Studies of nutrient absorption in vivo require comparison of the amounts of nutrient in the food and unabsorbed food residues. The obvious way of achieving this comparison is to make a total collection of the residues derived from a particular quantity of food. Edin ( 1926 ) found that since chromium sesquioxide (chromic oxide, $\mathrm{Cr}_{2} \mathrm{O}_{3}$ ) was a nutritionally inert, and non-absorbed indicator, it was suitable as an indicator for use in studies in which the progress of absorption was to be determined by comparing the ratios of nutrient to indicator in food and food residues. Carlson \& Bayley (1968), however, were unable to use $\mathrm{Cr}_{2} \mathrm{O}_{3}$ as an indicator because it separated from the lipid phase of the digesta in the stomach.

Borgström (1960) suggested that cholesterol, which is poorly absorbed and is lipidsoluble, could be used to indicate the progress of fat absorption through the intestinal tract; however, the poor recovery of cholesterol limits its usefulness. Sie, Valkema \& Loomeijer ( 1967 ) suggested using a silicone oil, but the quantitative determination of the silicone oil was tedious. Spener, Paltauf \& Holasek (r968) used glyceryl trioleyl ether as a model for triglycerides in studies of fat absorption and found that this compound was not absorbed. Thus it could possibly be useful as an indicator of lipid absorption, particularly if it did not separate from the lipid component of the digesta in the stomach.

The present study describes the synthesis and purification of tridodecyl glyceryl ether ( $1,2,3$-tridodecoxypropane) (DGE) and its quantitative determination by gas- 
liquid chromatography. The recovery of the DGE was compared with that of $\mathrm{Cr}_{2} \mathrm{O}_{3}$ when these indicators were included in a diet given to rats, and the degree to which both indicators remained in association with the lipid phase of the digesta during its passage from the stomach to the small intestine was measured in young pigs. A brief account of this work has been presented (Carlson \& Bayley, 1970a) and Morgan \& Hofmann $(x 970 b)$ have also described the use of a tritium-labelled trialkyl glyceryl ether as an indicator in fat-digestibility studies.

\section{EXPERIMENTAL}

\section{Preparation of $D G E$}

The DGE was synthesized from allyl alcohol, dodecanol, methane sulphonyl chloride and I,4-dihydropyran (Eastman Organic Chemicals, Rochester, New York) by the method of Paltauf \& Spener ( 1968 ) with the following modifications: pellets of potassium hydroxide were used rather than a powder and thus longer times were needed for the completion of the reactions, and a water-separator was essential throughout all stages involving the use of potassium hydroxide. The crude 1,2 -didodecoxypropane was recrystallized from absolute ethanol before it was used for the synthesis of the DGE.

The DGE was purified in two stages: by recrystallizing from ethanol and by adsorption chromatography. The crude DGE was dissolved in 20 volumes of ethanol at $20^{\circ}$ and allowed to crystallize at $4^{\circ}$ overnight; these crystals were recovered and dissolved in a minimum volume of hexane. This differed from the procedure employed by Paltauf \& Spener ( 1968 ), who purified small quantities of their product by thin-layer chromatography.

A ${ }_{5} 5 \times 7.5 \mathrm{~cm}$ glass column was packed with $3 \mathrm{~kg}$ silica gel (28-200 mesh, grade I 2; Davison Chemicals, Baltimore, Maryland) added as a slurry with hexane. The column was conditioned by washing it with 51 anhydrous diethyl ether, followed by 51 hexane before applying the hexane solution containing $30 \mathrm{~g}$ of recrystallized DGE. Hexane $\left(\mathrm{r}_{5} \mathrm{l}\right)$ was used to elute the other reaction products, including didodecyl ether, after which the DGE was eluted with $4514 \%(\mathrm{v} / \mathrm{v})$ anhydrous diethyl ether in hexane.

Thin-layer chromatography showed that the recovered triether was composed of a single component which was characterized using infrared and nuclear magnetic resonance spectra, and elemental analyses (carbon, hydrogen and oxygen).

\section{Quantitative determination of $D G E$ by gas-liquid chromatography}

I,2-Didodecoxy,3-tetradecoxypropane (TDGE) was prepared by substituting tetradecylmethane sulphonate, prepared from tetradecanol (Eastman Organic Chemicals, Rochester, New York,) for didodecylmethane sulphonate in the synthesis described above. The TDGE was used as an internal standard for quantitative gasliquid chromatography.

The triethers were dissolved in carbon disulphide and injected into $100 \mathrm{~cm} \times 4 \mathrm{~mm}$ glass columns packed with I $\%$ silicone OV-25 (Applied Science Laboratories, State College, Pennsylvania) on Chromosorb G (AW-DMCS, 80-100 mesh; Chromato- 


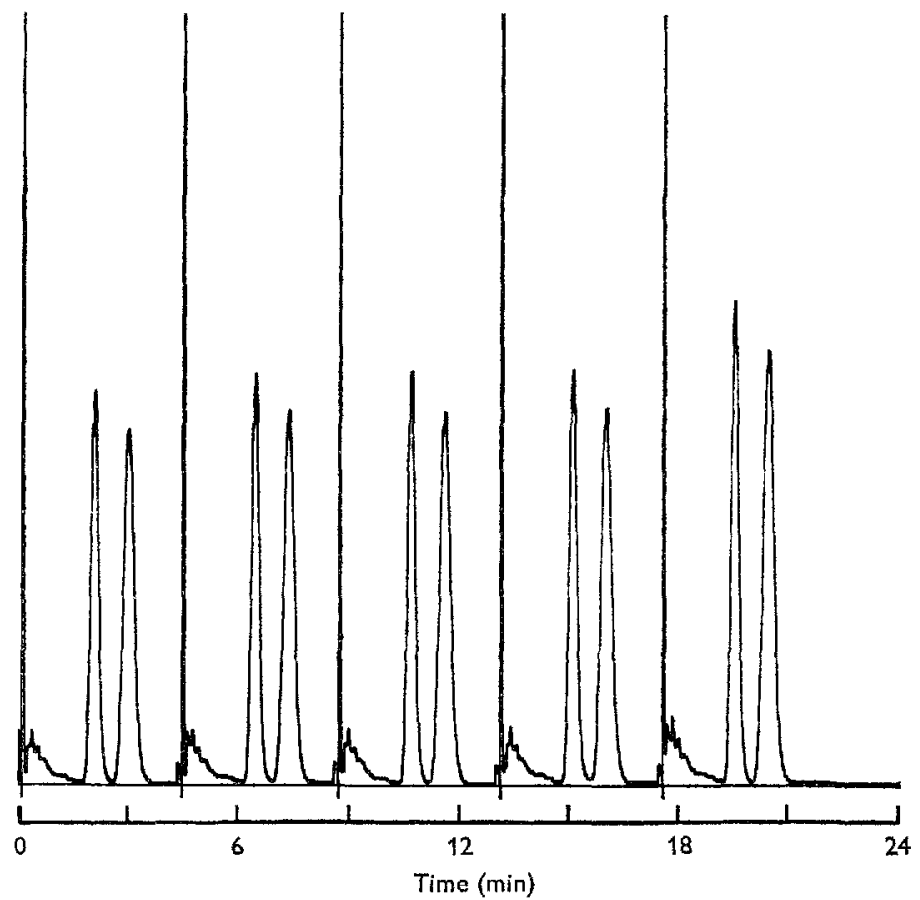

Fig. I. A chromatogram showing the separation of r,2,3-tridodecyl glyceryl ether (first major peak) and 1,2-didodecyl,3-tetradecyl glyceryl ether (second major peak) for five successive injections in to a $100 \mathrm{~cm} \times 4 \mathrm{~mm}$ glass column packed with $\mathrm{I} \%$ silicone $\mathrm{OV-25}$ on Chromosorb G. The small early peak represents the solvent. The column temperature was held at $290^{\circ}$ with the injector and detector ports at $300^{\circ}$. The Barber Colman series 5000 gas chromatograph was equipped with dual hydrogen-flame ionization detectors. The gas flowrates were: 35,30 and $300 \mathrm{ml} / \mathrm{min}$ for nitrogen, hydrogen and air respectively.

graphic Specialties, Brockville, Ontario). The temperatures of the column, injection port and detectors were 290,300 and $300^{\circ}$ respectively. The gas-liquid chromatograph (Series 5000; Barber Colman, Rockford, Illinois) was equipped with hydrogenflame ionization detectors. The gas flow-rates were 35,30 and $300 \mathrm{ml} / \mathrm{min}$ for nitrogen, hydrogen and air, respectively. Fig. $\mathrm{I}$ is a chromatogram of five successive injections of a sample containing DGE and TDGE.

\section{Animal experiments}

Expt $\mathrm{x}$. Fifteen male rats, weighing $200 \mathrm{~g}$ (Wistar strain; Woodlyn Farms, Guelph, Ontario), received the diet (Table I) which contained $0.25 \%(\mathrm{w} / \mathrm{w}) \mathrm{Cr}_{2} \mathrm{O}_{3}$ and $0.1 \%$ $(\mathrm{w} / \mathrm{w})$ DGE. The DGE was dissolved in the dietary fat, which was melted before it was added to the rest of the dietary ingredients. The rats were housed in individual cages which allowed the separation and collection of faeces and urine. Each rat received $\mathrm{I} 6 \mathrm{~g}$ food $/ \mathrm{d}$ (approximately $80 \%$ of $a d l i b$. intake) for $\mathrm{I} 3 \mathrm{~d}$. The faeces voided during the first $3 \mathrm{~d}$ were discarded and then a total collection from each rat was made over the next ro $\mathrm{d}$. On the final day of the collection period, $3 \mathrm{~h}$ after being fed, each rat was anaesthetized with diethyl ether and as soon as it was immobilized it was killed 


\section{Table I. Composition of the diet}

\begin{tabular}{|c|c|}
\hline Ingredient & $\%$ \\
\hline Soya-bean protein flour ( $70 \%$ crude protcin) $)^{*}$ & $3^{8}$ \\
\hline Maize starcht & $18 \cdot 55$ \\
\hline Cerelosef & 25 \\
\hline Cellulose & 2 \\
\hline Beef tallows & IO \\
\hline Calcium phosphate $(18.5 \% \mathrm{Ca}, 20.0 \% \mathrm{P})$ & 3 \\
\hline Calcium carbonate & 1 \\
\hline DL-methionine & 0.6 \\
\hline $\mathrm{NaCl}$ (iodized) & 0.5 \\
\hline Vitamin supplement $\|$ & 0.5 \\
\hline Mineral supplement & 0.5 \\
\hline Chromic oxide $\left(\mathrm{Cr}_{2} \mathrm{O}_{3}\right)$ & 0.25 \\
\hline Tridodecyl glyceryl ether & $0 \cdot 1$ \\
\hline
\end{tabular}

* Skidmore Enterprises, Cincinnati, Ohio.

+ Brewers' corn grits, rolled (Canada Starch Company, Toronto, Ontario).

I Canada Starch Company, Toronto, Ontario.

$\S$ Glycerol tri[ $\left.x-{ }^{14} \mathrm{C}\right]$ oleate (Amersham/Searlc Corp., Des Plaines, Illinois) was added to the becf tallow to provide $25 \mu \mathrm{Ci}$ per $\mathrm{kg}$ of diet to make the ${ }^{14} \mathrm{C}$-labelled meal consumed by the pigs in Expt 2 immediately before being killed.

i| 'To supply per kg diet: retinol acetate, 2200 i.u.; cholecalciferol, 440 i.u.; cyanocobalamin, $44 \mu \mathrm{g}$; DL- $\alpha$-tocopherylacetate I $5 \mathrm{mg}$; riboflavin, $6 \mathrm{mg}$; D-calcium pantothenate, $28.4 \mathrm{mg}$; nicotinanide, $44 \mathrm{mg}$; folic acid, $2 \mathrm{mg}$; menaphthone sodium disulphate $3 \mathrm{H}_{2} \mathrm{O}, 0.2 \mathrm{mg}$; thiamin hydrochloride, $2.94 \mathrm{mg}$; pyridoxine, $3.62 \mathrm{mg}$; biotin, $0.2 \mathrm{mg}$; choline chloride, $3 \mathrm{~g}$.

if 'To supply per kg diet: manganese as $\mathrm{MnO}, 20 \mathrm{mg}$; copper as CuSO, $6 \mathrm{mg}$; iron as $\mathrm{FcSO}_{4}$, $80 \mathrm{mg}$; zinc as $\mathrm{ZnO}$, $50 \mathrm{mg}$; magnesium as $\mathrm{MgCO}_{2}, 400 \mathrm{mg}$; selenium as $\mathrm{Na}_{2} \mathrm{SeO}_{3}$, $0.1 \mathrm{mg}$.

by decapitation. All the contents of the following sections of the digestive tract were removed and frozen: stomach, mid fifth of the small intestine (jejunum), distal tenth of the small intestine (ileum), caecum and colon.

Expt 2. Eleven male piglets (Yorkshire $\times$ Lacombe; Connaught Laboratories, Toronto, Ontario) were weaned at $7 \mathrm{~d}$ of age and received the diet shown in Table $\mathrm{I}$. The piglets were housed in individual cages as described by Carlson \& Bayley ( $1970 b)$. Before being killed at $2 \mathrm{I}$ d of age, the piglets were fasted overnight and given a single $75 \mathrm{~g}$ meal of the diet containing $0.25 \%(\mathrm{w} / \mathrm{w}) \mathrm{Cr}_{2} \mathrm{O}_{3}$ and $0.1 \%$ (w/w) DGE to which was added glycerol tri[ $\left[{ }^{11} \mathrm{C}\right]$ oleate $(25 \mu \mathrm{Ci}$ per $\mathrm{kg}$ of diet). The labelled trioleate was added to the beef tallow before it was incorporated into the diet. The animals were killed, $3 \mathrm{~h}$ after receiving this meal, by injection of sodium pentobarbitol into the superior vena cava, as described by Carle \& Dewhirst (I942). The contents of the stomach, the mid fifth of the small intestine (jejunum) and the distal fifth of the small intestine (ileum) were removed and frozen with liquid nitrogen.

\section{Methods of analyses}

All samples were freeze-dried and ground. Lipid was extracted by method A of Kamer, Bokkel Huinink \& Weyers (1949) as modified by Braddock, Fleisher \& Barbero (1968). Total fatty acids were determined by titration; total lipid was determined by evaporation of an aliquot of the light petroleum extract and subsequent drying under reduced pressure at $60^{\circ}$ in an oven. DGE was determined in another aliquot; the TDGE was added to the aliquot as an internal standard and the triethers 
Table 2. Mean values with their standard errors and coefficients of variation (cv) for each step in the gas-liquid chromatographic determination of tridodecyl glyceryl ether

$$
\text { (No. of observations }=\text { twelve) }
$$

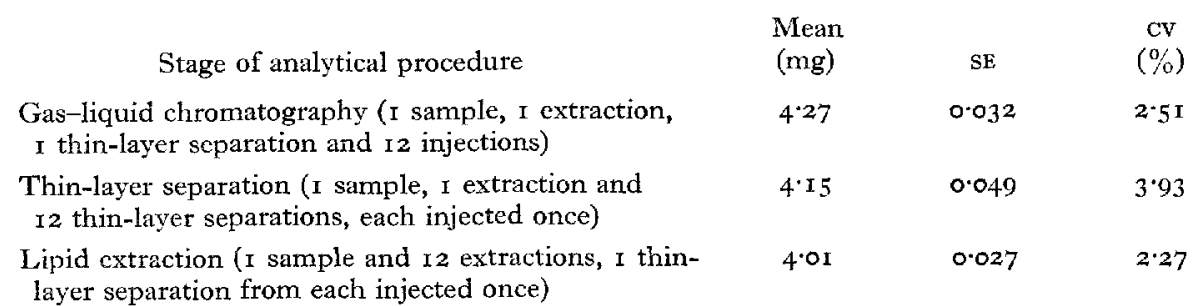

were separated from the other lipids by thin-layer chromatography using silica gel $G$ (Brinkman Instruments Inc., Westbury, New York); the plates were then developed with hexane: diethyl ether $(9: \mathrm{I}, \mathrm{v} / \mathrm{v})$. The bands were made visible by spraying the plates with dichlorofluorescein, and the bands containing triether were scraped off and extracted with chloroform. The chloroform was evaporated and the triethers were dissolved in carbon disulphide for analysis by gas-liquid chromatography.

To determine ${ }^{14} \mathrm{C}$ activity, two separate $10 \mathrm{ml}$ aliquots of the lipid extract were transferred to counting vials, the light petroleum was evaporated and the lipids were dissolved in $10 \mathrm{ml}$ of $6 \%(\mathrm{w} / \mathrm{v})$ PPO-POPOP in toluene (Spectrafluor, Amersham/ Searle Corp., Des Plaines, Illinois). The activity was determined in a liquid scintillation computer (Mark I, model 6860; Nuclear-Chicago Corp., Des Plaines, Illinois) and the results were corrected for counting efficiency using the channels-ratio method. Individual fatty acids were determined quantitatively as described by Carlson \& Bayley (1968).

Moisture was determined as weight loss at $105^{\circ}$ for $20 \mathrm{~h} ; \mathrm{Cr}_{2} \mathrm{O}_{3}$ was determined as chromium, using an atomic absorption spectrophotometer (type AA4; Techtron Pty, Melbourne, Australia) as described by Arthur (1970), after digestion of the samples by the method of Czarnocki, Sibbald $\&$ Evans (196r).

Statistical analyses were carried out as described by Steel \& Torrie (I960).

\section{Reproducibility of $D G E$ determination}

The main steps in the determination of the DGE in the samples of digesta were: (I) lipid extraction, (2) separation of the triethers from the other lipids by thin-layer chromatography, and (3) determination of the DGE by gas-liquid chromatography. The reproducibility of each stage was examined (Table 2) when twelve gas-liquid chromatograms were prepared either from a single thin-layer separation, or from twelve thin-layer separations from a single lipid extraction, or from twelve lipid extractions. Comparisons of the coefficients of variation show that none of the steps in the procedure added to variation inherent in the quantitative gas-liquid chromatography. 
RESUITS

\section{Recoveries of $D G E$ and $\mathrm{Cr}_{2} \mathrm{O}_{3}$ in faeces}

In Expt I there were no significant differences $(P<0.05)$ in the amounts of either indicator recovered from the rat faeces (Table 3 ), but both recoveries were significantly less $(P<0.001)$ than 100 . The apparent dry-matter digestibility coefficients, calculated using either $\mathrm{Cr}_{2} \mathrm{O}_{3}$ or DGE, were therefore not significantly different; nor were the coefficients of apparent lipid digestibility. Thus it appears that as a digestibility indicator the DGE is as good as the $\mathrm{Cr}_{2} \mathrm{O}_{3}$.

\section{Estimation of fatty-acid residues in digesta using $D G E$ and $\mathrm{Cr}_{2} \mathrm{O}_{3}$}

The quantities of fatty acids in the samples taken from different regions of the digestive tracts of the rats in Expt I were calculated on the basis of the residues per Ioo $\mathrm{g}$ food using the ratios of fatty acid to either indicator in the diet and the digesta.

Table 3. Expt $\mathrm{I}$. Percentage recovery of chromic oxide $\left(\mathrm{Cr}_{2} \mathrm{O}_{3}\right)$ and tridodecyl glyceryl ether (DGE) from faeces of the rats and the dry-matter and lipid digestibility coefficients (\%) calculated using total collection or $\mathrm{Cr}_{2} \mathrm{O}_{3}$ and $D G E$ as digestibility indicators. Mean values with their standard errors

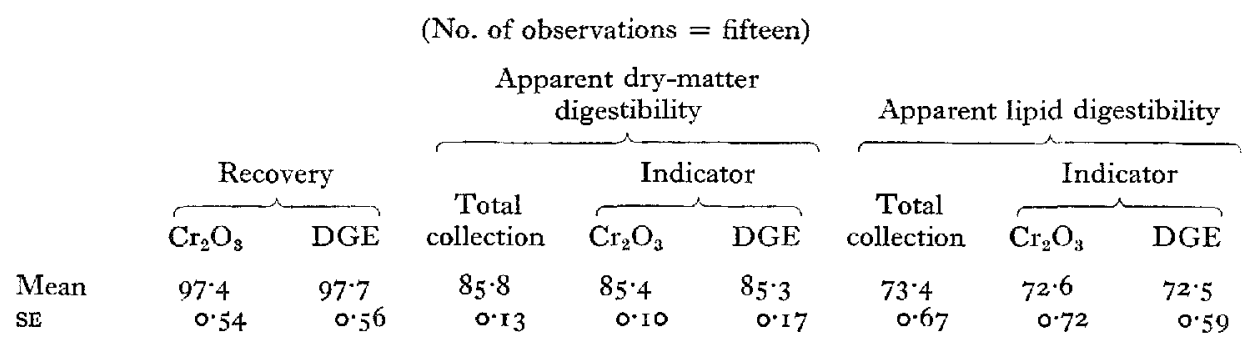

Table 4. Expt I. Residual amount $(\mathrm{g})$ of total fatty acids from $100 \mathrm{~g}$ of food found in the diet, in different regions of the digestive tract and in the faeces of rats, calculated using either chromic oxide $\left(\mathrm{Cr}_{2} \mathrm{O}_{3}\right)$ or tridodecyl glyceryl ether $(D G E)$ as an absorption indicator. Mean values with their standard errors for fifteen animals

\begin{tabular}{|c|c|c|c|c|}
\hline \multirow{3}{*}{$\begin{array}{l}\text { Origin of } \\
\text { sample }\end{array}$} & \multicolumn{4}{|c|}{ Total fatty aciỏs calculated from: } \\
\hline & \multicolumn{2}{|c|}{$\mathrm{Cr}_{2} \mathrm{O}_{3}$} & \multicolumn{2}{|c|}{ DGE } \\
\hline & Mean & SE & Mean & SE \\
\hline Diet & 10.0 & - & 10.0 & $一$ \\
\hline Stomach & I $8+8$ & $0.4 \mathrm{I}$ & $8 \cdot 4$ & 0.19 \\
\hline Jejunum & $8 \cdot 4$ & 0.78 & $3 \cdot 2$ & 0.27 \\
\hline Ileum & $2 \cdot 2$ & 0.30 & 0.9 & 0.03 \\
\hline Caecum & $I \cdot 9$ & 0.12 & 0.8 & 0.04 \\
\hline Colon & $2 \cdot 0$ & 0.37 & $I \cdot 3$ & 0.18 \\
\hline Faeces & $3 \cdot 4$ & 0.12 & $3 \cdot 4$ & 0.10 \\
\hline
\end{tabular}




\section{Association of $D G E$ and $\mathrm{Cr}_{2} \mathrm{O}_{3}$ with dietary fat and labelled triglyceride}

These values are compared in Table 4 with the amounts of fatty acid in the diet. On the basis of the amounts of $\mathrm{Cr}_{2} \mathrm{O}_{3}$ in the stomach contents, there appeared to be an increase in the amount of fatty acid, indicating partition of the fatty acids and the $\mathrm{Cr}_{2} \mathrm{O}_{3}$, with the particulate $\mathrm{Cr}_{2} \mathrm{O}_{3}$ passing out of the stomach more rapidly than the fat. Such a separation would preclude calculation of meaningful values for the amounts of fatty acid in the intestine derived from a given quantity of diet.

Further evidence against the use of $\mathrm{Cr}_{2} \mathrm{O}_{3}$ as an indicator of the absorption of fat is provided by the larger standard errors associated with the quantities of total fatty acids remaining unabsorbed in the stomach and jejunum when these are calculated using $\mathrm{Cr}_{2} \mathrm{O}_{3}$ than when calculated using the DGE. The unabsorbed dietary residues and the indicators remixed in the lower part of the digestive tract, and thus both indicators are of equal value for estimating the amounts of unabsorbed fatty acids in faeces. The similarity of the values and their small standard errors for the estimates of the fatty acids in the faeces for both indicators support this. Calculations using the DGE as indicator show a small reduction in the amount of fatty acid in the contents of the stomach, with the greater part of the absorption occurring before the digesta reached the end of the ileum. As the digesta passed through the large intestine there was an increase in the amount of fatty acid in the digesta derived from $100 \mathrm{~g}$ food, indicating a net addition of fatty acids into the lower part of the digestive tract. This change in the quantity of fatty acid can be compared with the change in fatty-acid composition shown to occur in the lower digestive tract (Carlson \& Bayley, I968).

Comparison of the diet and the stomach contents for the pigs in Expt 2 (Table 5)

Table 5. Expt 2. Concentrations of ${ }^{14} \mathrm{C}$-label tridodecyl glyceryl ether (DGE) and chromic oxide $\left(\mathrm{Cr}_{2} \mathrm{O}_{3}\right) *$ and the ratio of ${ }^{14} \mathrm{C}: \mathrm{DGE}$ and ${ }^{14} \mathrm{C}: \mathrm{Cr}_{2} \mathrm{O}_{3}$ in the labelled diet, and mean values with their standard errors in the stomach, the jejunal and the ileal digesta for eleven piglets

\begin{tabular}{|c|c|c|c|c|c|c|c|}
\hline \multirow[b]{2}{*}{ Analyses and ratios } & \multirow{2}{*}{$\begin{array}{l}\text { Labelled } \\
\text { diet }\end{array}$} & \multicolumn{2}{|c|}{ Stomach } & \multicolumn{2}{|c|}{ Jejunum } & \multicolumn{2}{|c|}{ Ileum } \\
\hline & & Mean & $\mathrm{SE}$ & Mean & SE & Mean & $\mathrm{SE}$ \\
\hline & \multicolumn{7}{|c|}{ Concentrations in sample } \\
\hline $\begin{array}{l}\text { Total fatty acids } \\
(\mathrm{mg} / \mathrm{g})\end{array}$ & 107 & r64 & 50 & 102 & 24 & $9 \mathrm{I} \cdot 3$ & 32 \\
\hline${ }^{14} \mathrm{C}\left((\right.$ counts $/ \mathrm{min}) \times 10^{-5}$ & (g) 0.79 & $\mathrm{I} \cdot \mathrm{I} 8$ & 0.12 & 0.65 & 0.05 & 0.27 & 0.09 \\
\hline DGE (mg/g) & 0.93 & 1.40 & 0.04 & $\mathrm{r} \cdot \mathbf{2 3}$ & 0.08 & $2 \cdot 26$ & 0.24 \\
\hline \multirow[t]{2}{*}{$\mathrm{Cr}_{2} \mathrm{O}_{3}(\mathrm{mg} \times 0.37 \mathrm{r} / \mathrm{g})$} & 0.93 & $\mathrm{I} \cdot \mathrm{x} I$ & 0.16 & $I \cdot 26$ & $0 \cdot 13$ & $2 \cdot 12$ & 0.12 \\
\hline & \multicolumn{7}{|c|}{ Total fatty acids:indicator ratios } \\
\hline Total fatty acids: DGE & II5 & II 7 & $2 \cdot 34$ & 83 & 3.94 & 44 & $6 \cdot 53$ \\
\hline \multirow{2}{*}{ Total fatty acids: $\mathrm{Cr}_{2} \mathrm{O}_{3}$} & I 5 & r 39 & $3 \cdot 80$ & 85 & $6 \cdot 00$ & 47 & 9.0o \\
\hline & \multicolumn{7}{|c|}{${ }^{14} \mathrm{C}$ :indicator ratios } \\
\hline${ }^{14} \mathrm{C}: \mathrm{DGE}$ & 0.85 & 0.84 & 0.01 & 0.53 & 0.03 & 0.14 & 0.06 \\
\hline${ }^{14} \mathrm{C}: \mathrm{Cr}_{2} \mathrm{O}_{3}$ & 0.85 & $x \cdot \infty$ & 0.03 & 0.55 & 0.05 & 0.16 & 0.08 \\
\hline
\end{tabular}

* The units for $\mathrm{Cr}_{2} \mathrm{O}_{3}$ were adjusted to bring them to the same base as DGE by multiplying the mg/g by 0.37 I (the ratio of DGE: $\mathrm{Cr}_{2} \mathrm{O}_{3}$ in the diet) so that the ratios of either total fatty acid or of ${ }^{14} \mathrm{C}$ to both indicators could be compared direct. 
shows an increase in the concentration of ${ }^{14} \mathrm{C}$, DGE and $\mathrm{Cr}_{2} \mathrm{O}_{3}$ in the digesta dry matter, due to the faster passage of the water-soluble dietary components out of the stomach. The ratios ${ }^{14} \mathrm{C}$ : DGE in the diet and stomach contents were unchanged $(0.85$ and 0.84 ) whereas the ratios ${ }^{14} \mathrm{C}: \mathrm{Cr}_{2} \mathrm{O}_{3}$ increased from 0.85 to $\mathrm{I} \cdot 00$, again indicating more rapid passage of the $\mathrm{Cr}_{2} \mathrm{O}_{3}$ than of fat from the stomach to the small intestine. This further confirms the conclusion that the DGE is a more useful indicator of fattyacid absorption from the digestive tract than $\mathrm{Cr}_{2} \mathrm{O}_{3}$.

The concentrations of ${ }^{14} \mathrm{C}$ in the stomach, jejunum and ileum show the progress of absorption of the label, but these concentrations alone do not represent absolute absorptions. The increase in concentration of the indicators shows the extent of apparent absorption of the dietary components, and the ratios ${ }^{14} \mathrm{C}: \mathrm{DGE}$ and ${ }^{14} \mathrm{C}: \mathrm{Cr}_{2} \mathrm{O}_{3}$ can be used to calculate absorbabilities. In fact, the ratios were similar for both indicators in the samples taken from jejunum and ileum, suggesting that, in spite of the separation of $\mathrm{Cr}_{2} \mathrm{O}_{3}$ and fat which occurs in the stomach, $\mathrm{Cr}_{2} \mathrm{O}_{3}$ may be a useful absorption indicator because of this remixing.

Table 6. Expt 2. Percentage apparent absorption of total fatty acids and ${ }^{14} \mathrm{C}$ as calculated using either chromic oxide $\left(\mathrm{Cr}_{2} \mathrm{O}_{3}\right)$ or tridodecyl glyceryl ether $(D G E)$ as the indicator for eleven piglets. Mean values with their standard errors

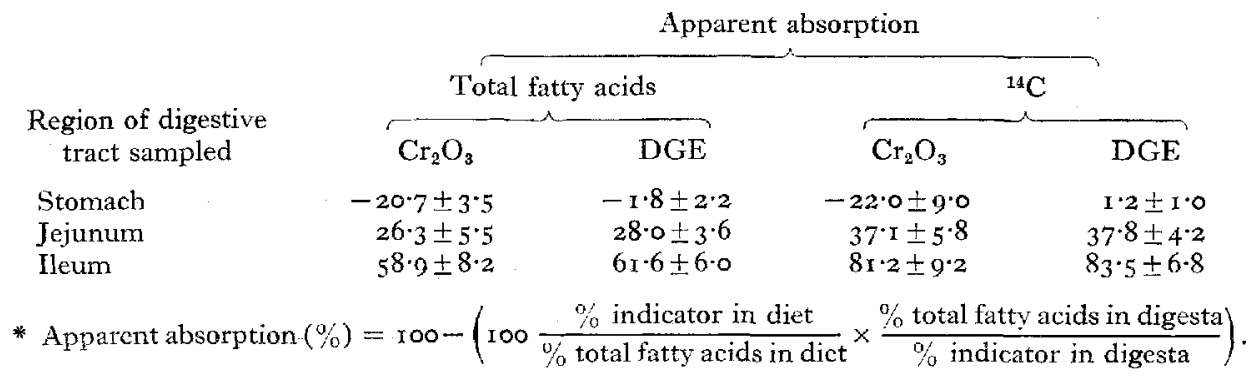

The apparent absorbabilities of the total fatty acids and ${ }^{14} \mathrm{C}$ label (Table 6) illustrate the apparent negative absorbabilities of the lipids from the stomach, calculated using $\mathrm{Cr}_{2} \mathrm{O}_{3}$ as indicator, but show that both indicators give similar results for the jejunum and ileum. Analyses of the jejunal samples indicated that the ${ }^{14} \mathrm{C}$ label was absorbed more completely than the total fatty acids. A similar comparison for the ileal samples showed a much greater absorption of the label than of the total fatty acids. This is to be expected since the ${ }^{14} \mathrm{C}$ absorbability represents a true absorbability of the unsaturated oleic acid, if it is assumed that little of the ${ }^{14} \mathrm{C}$-labelled oleic acid which was absorbed would appear in the ileal digesta. In contrast, the absorbability of the total fatty acids represents apparent values for the mixture of fatty acids in the beef tallow.

An alternative possibility is that the more saturated fatty acids accumulated in the mucosal cells, and that shedding of these cells immediately post mortem would increase the concentration of saturated fatty acids relative to the unsaturated fatty acids in the digesta. It seems unlikely, however, that sloughing of mucosal cells would make a substantial contribution to the fat in the digesta. 

Table 7. Expt 2. Fatty acids in the diet and in the digesta (as \% of total fatty acids) in piglets

\begin{tabular}{|c|c|c|c|c|c|c|c|}
\hline \multirow[b]{2}{*}{$\begin{array}{l}\text { Origin of } \\
\text { sample }\end{array}$} & \multicolumn{7}{|c|}{ Fatty acid } \\
\hline & $14: 0$ & I $6: 0$ & I $6:$ I & $\overbrace{18: 0}^{2}$ & $x 8: 1$ & $18: 2$ & $18: 3$ \\
\hline Diet & $2 \cdot 6$ & $23 \cdot 0$ & $3 \cdot 2$ & $2 I \cdot 9$ & $37 \cdot 9$ & $5 \cdot 9$ & $1: 4$ \\
\hline Stomach & $2 \cdot 9$ & $24^{\circ} I$ & $2 \cdot 7$ & $22 \cdot 0$ & $39 \cdot 6$ & $4 \cdot 4$ & $I \cdot I$ \\
\hline Jejunum & $2 \cdot 1$ & $23 \cdot 2$ & $2 \cdot 5$ & $24 \cdot 6$ & $37 \cdot 6$ & $5 \cdot I$ & $I \cdot I$ \\
\hline Ileum & $1 \cdot 6$ & 30.9 & 0.5 & $4 I^{\prime} 5$ & $16 \cdot 3$ & $3 \cdot 2$ & 0.6 \\
\hline
\end{tabular}

Table 8. Expt 2. Amounts and radioactivities of oleic acid ${ }^{*}$ in the diet and in the digesta of piglets

\begin{tabular}{|c|c|c|c|}
\hline Origin of sample & $\begin{array}{c}{ }^{14} \mathrm{C} \\
\left((\text { counts } / \mathrm{min}) \times 10^{-4}\right. \\
\text { per } \mathrm{g} \\
\text { dry sample })\end{array}$ & $\begin{array}{l}\text { Olejc acid } \\
(\mathrm{mg} / \mathrm{g} \text { of } \\
\text { freeze-dried } \\
\text { sample) }\end{array}$ & $\begin{array}{c}\text { Specific activity } \\
\text { of oleic acid } \\
\left((\text { counts } / \mathrm{min}) \times 10^{-3}\right. \\
\text { per } \mathrm{mg})\end{array}$ \\
\hline Diet & $7 \cdot 89$ & 43 & $\mathbf{I} \cdot 8$ \\
\hline Stomach & I 178 & 65 & $1 \cdot 8$ \\
\hline Jejunum & $6 \cdot 44$ & 38 & $1 \cdot 7$ \\
\hline Ileum & $2 \cdot 71$ & I5 & $\mathbf{I} \cdot 8$ \\
\hline
\end{tabular}

The compositions of the fatty acids in the stomach and jejunal contents were similar to that of the diet (Table 7), but the relative proportions of palmitic and stearic acids were greater in the ileal digesta, with corresponding decreases in the proportions of the unsaturated fatty acids. These changes in fatty-acid composition of the digesta during passage through the small intestine could result either from selective absorption of the unsaturated fatty acids, or from dilution of the dietary fat by secretion of a relatively saturated mixture of fatty acids. However, the latter is unlikely, since the change in fatty-acid composition was not apparent in the jejunal digesta, which contained the pancreatic secretions.

An indication of the dilution of the oleic acid can be obtained from the specific activities of the oleic acid in the diet and digesta (Table 8); since these did not change it appears that there was no appreciable net dilution of the exogenous oleic acid with endogenous secretions.

\section{I SCUSSION}

The results of these studies extend the usefulness of glycerol triethers from indicators of fat digestibility to indicators which allow study of the progress of fat absorption in different regions of the digestive tract.

Purification by adsorption chromatography on silica gel which had been conditioned with diethyl ether produced pure DGE in a single passage through the column, whereas elution from a silicic acid column with hexane which was progressively diluted with benzene (Morgan \& IIofmann, I970a) requires two passages through the column to produce pure DGE. Quantitative determination of non-labelled triether by gas-liquid chromatography was suggested by Morgan \& Hofmann (I97oa), but they 
did not use this method in their experiments. The lipid-soluble indicator, which can be determined in a sample of the extract prepared for fatty-acid determination, considerably reduces the number of laboratory manipulations necessary for routine studies of fat absorption.

The recoveries of dietary DGE and $\mathrm{Cr}_{2} \mathrm{O}_{3}$ in the faeces compare favourably with those reported by other workers using various indicators: Davignon, Simmonds \& Ahrens (I968) reported recoveries of $98.7 \pm 2.6 \%$ for man under steady-state conditions of intake and output of $\mathrm{Cr}_{2} \mathrm{O}_{3}$, Sie et al. ( 1967 ) reported a recovery of $93 \cdot 2 \pm \mathrm{I} \cdot 8 \%$ of silicone oil from rats, and Morgan \& Hofmann ( $1970 \mathrm{a}$ ) recovered $93.3 \%$ of the label after administration of a triether by gastric intubation, though only $80 \%$ was recovered by Morgan \& Iofmann (1970 b) when faeces were collected after administration of the label in a single test meal-this could be an underestimate because collection of faeces was discontinued after $3 \mathrm{~d}$.

The incomplete recovery of DGE $(97.7 \%)$ and of the $\mathrm{Cr}_{2} \mathrm{O}_{3}(97.4 \%)$ was probably due to limitations of the techniques used rather than absorption by the rats, since Spener et al. (I968) showed that less than $0.14 \%$ of the administered radioactivity was found in the body of the rats which had received a labelled triether.

Small (1970) showed that non-polar compounds such as the DGE used in this experiment remained in the oil-phase during the formation of micellar solutions, thus accounting for the non-absorption and faecal recovery of the triether used in this study. Freeman, Noakes, Annison \& Hill (1968) concluded that the capacity to absorb micellar lipid is unlikely to be exceeded by the rate of production of micelles in the small intestine, and thus, if there is no accumulation of triether-free micellar lipid in the digesta, the triether would remain in association with the dietary lipid. However, in Expt $\mathrm{I}$ there was an indication of some absorption of fat from the stomach, based on the decrease in the ratio of fat:DGE in the stomach contents compared with that in the food. This is unlikely to have resulted from fatty-acid absorption, but rather from partial hydrolysis of the dietary fat (Clark, Brouse \& Holt, 1969), with the formation of a more hydrophilic phase free of DGE which moved out of the stomach faster than did the lipid phase which contained the DGE. There was no evidence of absorption from the stomachs of the pigs used in Expt 2.

It is well recognized that unsaturated fatty acids are more readily absorbed than saturated fatty acids, and the greater proportion of saturated acids in the ileal than in the jejunal digesta are consistent with this. The change in fatty-acid composition could have resulted from a combination of at least three factors, namely preferential solubilization of unsaturated fatty acids into the micellar phase (Carey \& Small, I970), selective incorporation of unsaturated fatty acids from newly absorbed micelles into chylomicron triglyceride (McKay, Kaunitz, Csavossy \& Johnson, I967), or endogenous secretion of saturated fatty acids (Freeman, Holme \& Annison, I968).

The results of the studies reported here suggest that DGE fulfils the following criteria for an ideal fat-absorption indicator: it was not absorbed and was recovered unaltered in the faeces, it remained in a homogeneous mixture with the dietary fat during the passage of the digesta through the gastro-intestinal tract, and it could be determined quantitatively. 
The advice and guidance given by Drs J. B. Rattray, S. J. Slinger and J. D. Summers during the studies of which the research formed a part are gratefully acknowledged. The work was supported by the Canada Department of Agriculture.

\section{REFERENCES}

Arthur, D. (1970). Can. Spectroscopy $\mathbf{1 5}, \mathrm{I}$.

Borgström, B. (I960). J. clin. Invest. 39, 809.

Braddock, I. I., Flcisher, D. R. \& Barbero, G. J. (I 968). Gastroenterology 55, 165.

Carey, M. C. \& Small, D. M. (1970). Am. F. Med. 49, 590.

Carle, B. N. \& Dewhirst, W. H. (1942). F. Am. vet. Med. Ass. ror, 495.

Carlson, W. E. \& Bayley, H. S. (1968). Can. Y. Anim. Sci. 48, 3 I 5.

Carlson, W. E. \& Bayley, H. S. (1970a). Fedn Proc. Fedn Am. Socs exp. Biol. 29, 300.

Carlson, W. E. \& Bayley, H. S. (1970b). Lab. Anim. Care zo, i 56.

Clark, S. B., Brause, B. \& Holt, P. R. (I969). Gastroenterology 56, 2 I4.

Czarnocki, J., Sibbald, I. R. \& Evans, E. V. (196r). Can. F. Anim. Sci. 4I, r67.

Davignon, J., Simmonds, W. J. \& Ahrens, E. H., Jr (I 968). F. clin. Invest. 47, 127.

Edin, H. (1926). Fortsatta Försök med Indirekta pa 'Ledkroppsprincipen' Grundade Metoder för Bestämning av Fodrets Shältbarhet. Kromoxid som 'Ledkropp' (Kvantitative Indikator). Centralanst. f. försöksväs, jordbruksområdet, medd, p. 309.

Freeman, C. P., Holme, D. W. \& Annison, E. F. (1968). Br. F. Nutr. 22, 65 I.

Freeman, C. P., Noakes, D. E., Annison, E. F. \& Hill, K. J. (1968). Br. F. Nutr. 22, 739.

Kamer, J. H. van de, Bokkel Huinink, H. ten B. \& Weyers, H. A. (1949). 7. biol. Chem. 177, 347.

McKay, D. G., Kaunitz, H., Csavossy, I. \& Johnson, R. E. ( 967 ). Metabolism r6, 137.

Morgan, R. G. H. \& Hofmann, A. F. (1970a). J. Lipid Res. II, 223.

Morgan, R. G. H. \& Hofmann, A. F. (1970b). \%. Lipid Res. Ir, 23 I.

Paltauf, F. \& Spener, F. (1968). Chem. Phys. Lipids 2, х68.

Sie, H. G., Valkema, A. J. \& Loomeijer, F. J. (1967). 7. Lab. clin. Med. 69, 989.

Small, D. M. (r 970). Fedn Proc. Fedn Am. Socs exp. Biol. 29, I 320.

Spener, F., Paitauf, F. \& Holasek, A. (1968). Biochim. biophys. Acta 552, 368.

Steel, R. G. D. \& Torrie, J. H. (1960). Principles and Procedures of Statistics. New York and Iondon: McGraw-Hill. 